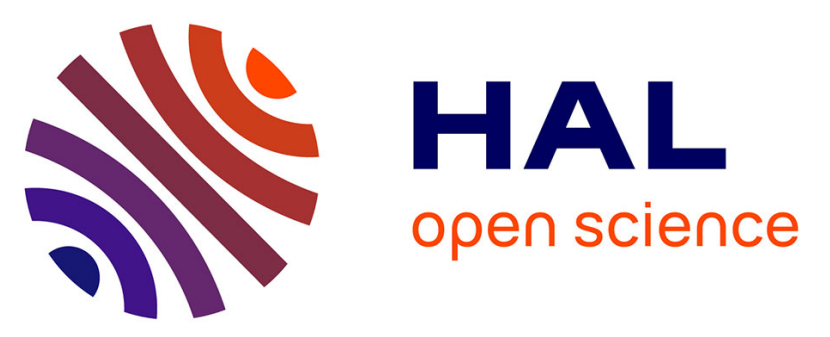

\title{
Lanthanide Luminescence Modulation by Cation- $\pi$ Interaction in a Bioinspired Scaffold: Selective Detection of Copper(I)
}

Manon Isaac, Sergey A. Denisov, Amandine Roux, Daniel Imbert, Gediminas Jonusauskas, Nathan Mc Clenaghan, Olivier Sénèque

\section{To cite this version:}

Manon Isaac, Sergey A. Denisov, Amandine Roux, Daniel Imbert, Gediminas Jonusauskas, et al.. Lanthanide Luminescence Modulation by Cation- $\pi$ Interaction in a Bioinspired Scaffold: Selective Detection of Copper(I). Angewandte Chemie International Edition, 2015, 54 (39), pp.11453-11456. 10.1002/anie.201505733 . hal-01211550

\section{HAL Id: hal-01211550 \\ https://hal.science/hal-01211550}

Submitted on 20 Feb 2018

HAL is a multi-disciplinary open access archive for the deposit and dissemination of scientific research documents, whether they are published or not. The documents may come from teaching and research institutions in France or abroad, or from public or private research centers.
L'archive ouverte pluridisciplinaire HAL, est destinée au dépôt et à la diffusion de documents scientifiques de niveau recherche, publiés ou non, émanant des établissements d'enseignement et de recherche français ou étrangers, des laboratoires publics ou privés.

\section{()(1)(2)}

Distributed under a Creative Commons Attribution - ShareAlikel 4.0 International 


\title{
Lanthanide Luminescence Modulation by Cation- $\pi$ Interaction in a Bioinspired Scaffold: Selective Detection of Copper(I)
}

\author{
Manon Isaac, Sergey A. Denisov, Amandine Roux, Daniel Imbert, Gediminas Jonusauskas, \\ Nathan D. McClenaghan,* and Olivier Sénèque*
}

\begin{abstract}
A prototype luminescent turn on probe for $\mathrm{Cu}^{+}$(and $\left.\mathrm{Ag}^{+}\right)$is described, harnessing a selective binding site $\left(\log \mathrm{K}_{\text {ass }}=\right.$ 9.4 and 7.3 for $\mathrm{Cu}^{+}$and $\mathrm{Ag}^{+}$, respectively) based on the coordinating environment of the bacterial metallo chaperone CusF, integrated with a terbium ion signaling moiety. Cation $\pi$ interactions were shown to enhance tryptophan triplet population, which subsequently sensitized, on the microsecond timescale, the long lived terbium emission, offering a novel approach in bioinspired chemosensor design.
\end{abstract}

Copper is an essential element for life ${ }^{[1]}$ It is required for various biological processes and its homeostasis is finely regulated in living organisms. ${ }^{[2]}$ Misregulation of copper can lead to various diseases (e.g., Menkes, Wilson, and Parkinson diseases). ${ }^{[3]}$ To better understand the biology of copper, techniques are required to detect and quantify it, knowing that extracellular copper is in the + II oxidation state, whereas mobile copper is in the reduced + I state in cells. Generally, fluorescence detection is considered to be one of the cheapest and easiest techniques. ${ }^{[4]}$ However, the design of fluorescent probes for $\mathrm{Cu}^{+}$is more challenging than many other cations, such as $\mathrm{Ca}^{2+}$ or $\mathrm{Zn}^{2+}$, because $\mathrm{Cu}^{+}$is an effective quencher of fluorescence through charge transfer and intersystem crossing (ISC) mechanisms. ${ }^{[5]}$ As turn on emission is preferred for detecting an analyte, $\mathrm{Cu}^{+}$selective fluorescent probes were designed in which the fluorophore is spatially disconnected from the chelate..$^{[5,6]}$ These probes rely on a photoinduced electron transfer (PET) mechanism in which the chelator, in its unbound form only, acts as an electron donor to the excited state of the fluorophore and quenches its emission. ${ }^{[5,6]}$ In this communication, we report a new type of turn on $\mathrm{Cu}^{+}$ responsive probe based on a lanthanide ion $\left(\mathrm{Ln}^{3+}\right)$ emitter, that has a long luminescence lifetime (in the millisecond range) compared to classical organic fluorophores (nano

[**] M. Isaac, Dr. A. Roux, Dr. O. Sénèque

Univ. Grenoble Alpes, LCBM/PMB, and CEA, IRTSV/CBM/PMB and CNRS, LCBM UMR 5249, PMB

38000 Grenoble (France)

E mail: olivier.seneque@cea.fr

Dr. S. A. Denisov, Dr. G. Jonusauskas, Dr. N. D. McClenaghan Univ. Bordeaux and CNRS, ISM (UMR 5255) and LOMA (UMR 5798) 33405 Talence (France)

E mail: nathan.mcclenaghan@u bordeaux.fr

Dr. D. Imbert

Univ. Grenoble Alpes and CEA, INAC/SCIB/RICC

38000 Grenoble (France)
A

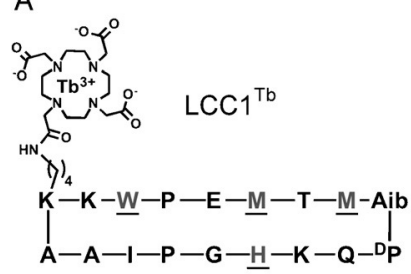

B
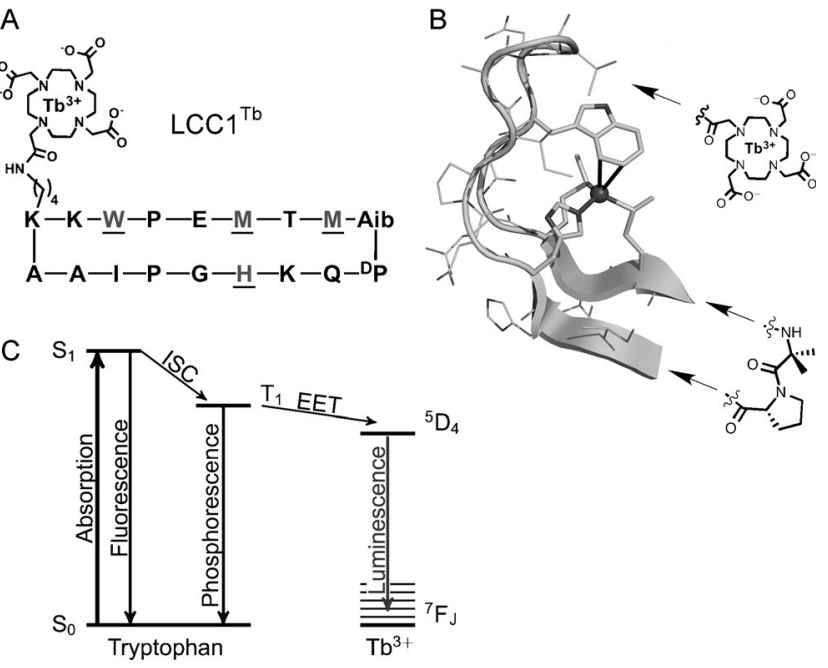

Figure 1. A) Amino acid sequence of $\mathrm{LCCl}^{\mathrm{Tb}}$, chelating moieties are underlined. B) Principle of the probe design based on the $\mathrm{X}$ ray structure of the $\mathrm{Cu}^{+}$binding loop of CusF ${ }^{[14]} \mathrm{C}$ ) Simplified Jablonski Perrin diagram of $\mathrm{LCCl}^{\mathrm{Tb}}$ probe and pertinent photophysical process es.

second range) and that allows time gated detection to suppress background fluorescence contributions. ${ }^{[7}$ 10]

Our probe structure (Figure 1A) is inspired by the metal binding site of the metallo chaperone CusF, ${ }^{[11]}$ which is part of the CusCFBA system responsible for copper or silver detoxification in gram negative bacteria. ${ }^{[12]} \mathrm{CusF}$ binds either $\mathrm{Cu}^{+}$or $\mathrm{Ag}^{+}$by the side chains of four amino acids: two methionines $(\mathrm{M})$, a histidine $(\mathrm{H})$, and a tryptophan $(\mathrm{W})$ as shown in Figure 1B (right). ${ }^{[13,14]}$ Indeed, the indole ring of the tryptophan establishes a cation $\pi$ interaction with the metal ion that red shifts the $\pi \pi^{*}$ transition of the indole and fully quenches its fluorescence. ${ }^{[14]}$ Metal cation $\pi$ interactions are known to efficiently enhance ISC and increase the population of the excited triplet state of a fluorophore, thereby quenching the fluorescence. ${ }^{[15]}$

$\mathrm{Ln}^{3+}$ ions have desirable luminescence properties that make them prime candidates for biological applica tions. ${ }^{[8,9,16,17]}$ Direct lanthanide excitation is inefficient because $4 \mathrm{f} 4 \mathrm{f}$ transitions are Laporte forbidden. However, indirect excitation of $\mathrm{Ln}^{3+}$ ions is possible in complexes incorporating a chromophore that, once excited, transfers its energy to the lanthanide (this photosensitization process has been deemed an antenna effect) ${ }^{[18]}$ One of the main pathways for lanthanide sensitization involves electronic energy trans fer (EET) from the excited triplet state of the antenna to the 
emissive $\mathrm{Ln}^{3+}$ ion (Figure 1C). ${ }^{[7,18]}$ Among natural amino acids, tryptophan is an efficient antenna for $\mathrm{Tb}^{3+}$ sensitiza tion. ${ }^{[19]}$ Therefore, we designed a probe based, on the one hand, on a peptide mimicking the $\mathrm{Cu}^{+}$binding site of CusF providing high affinity and selectivity and, on the other hand, on a $\mathrm{Tb}^{3+}$ complex as signaling unit. We reasoned that we could benefit from an ISC enhancement due to a cation $\pi$ interaction between $\mathrm{Cu}^{+}$and the tryptophan to increase the population of the tryptophan excited triplet state and, subsequently, increase also the population of $\mathrm{Tb}^{3+}$ excited states to transduce the copper binding event into an increased $\mathrm{Tb}^{3+}$ emission.

The peptidic probe, namely $\mathrm{LCC}^{\mathrm{Tb}}$ (Figure $1 \mathrm{~A}$ and $\mathrm{B}$ ), comprises 1) the 16 amino acid sequence of the $\mathrm{Cu}^{+}$binding loop of CusF, which includes the four metal binding amino acids (see above), 2) an Aib ${ }^{D}$ Pro dipeptide ${ }^{[20]}$ to cyclize the loop and preorganize it, and 3) a DOTA macrocycle grafted on the amine side chain of a lysine to bind a $\mathrm{Tb}^{3+}$ ion. $\mathrm{LCC1}^{\mathrm{Tb}}$ was synthesized by a combination of solid phase and solution reactions (Supporting Information, SI). The metal binding properties of $\mathrm{LCC1}^{\mathrm{Tb}}$ were investigated under argon by circular dichroism (CD) spectroscopy (Figure 2). The titra
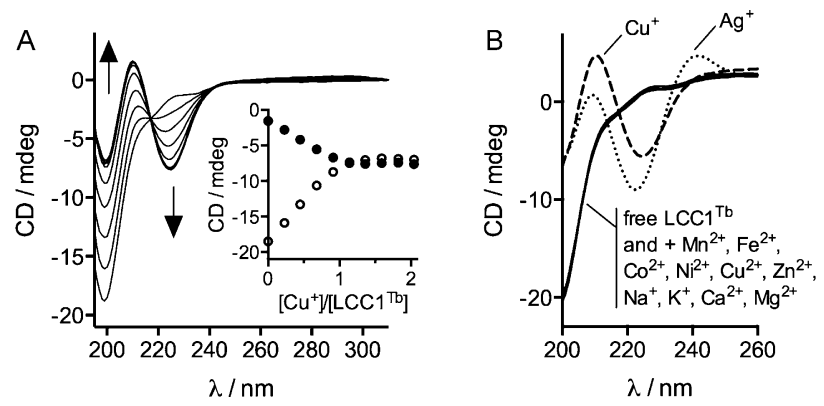

Figure 2. A) $\mathrm{CD}$ titration of $\mathrm{LCCl}^{\mathrm{Tb}}(16 \mu \mathrm{M})$ in phosphate buffer $(10 \mathrm{~mm}, \mathrm{pH} 7.5)$ by $\mathrm{Cu}^{+}$generated in situ by reduction of $\mathrm{CuSO}_{4}$ by $\mathrm{NH}_{2} \mathrm{OH}(2 \mathrm{~mm})$. The inset shows the evolution of the $\mathrm{CD}$ signal at $200 \mathrm{~nm}(\bigcirc)$ and $225 \mathrm{~nm}(\bullet)$. B) CD spectra of $\mathrm{LCCl}^{\mathrm{Tb}}(18 \mu \mathrm{M})$ before and after addition of various metal ions.

tion of $\mathrm{LCC}^{\mathrm{Tb}}$ in phosphate buffer $(10 \mathrm{~mm}, \mathrm{pH} 7.5)$ by $\mathrm{Cu}^{+}$, generated in situ by reduction of $\mathrm{Cu}^{2+}$ by $\mathrm{NH}_{2} \mathrm{OH}$, shows a linear evolution of the $\mathrm{CD}$ signal which reaches a plateau in the presence of 1.0 equiv $\mathrm{Cu}^{+}$, indicating the formation of a 1:1 complex, $\mathrm{Cu}^{\mathrm{I}} \cdot \mathrm{LCC}^{\mathrm{Tb}}$, which was confirmed by ESI MS analysis (SI). The same behavior is observed with $\mathrm{Ag}^{+}$due to the similarity between these two ions. $\mathrm{LCC}^{\mathrm{Tb}}$ is not able to bind any of the other physiologically relevant metal ions $\left[\mathrm{Na}^{+}\right.$, $\mathrm{K}^{+}$(100 mM), $\mathrm{Ca}^{2+}, \mathrm{Mg}^{2+}(10 \mathrm{~mm}), \mathrm{Mn}^{2+}, \mathrm{Fe}^{2+}, \mathrm{Co}^{2+}, \mathrm{Ni}^{2+}$, $\mathrm{Cu}^{2+}$, and $\left.\mathrm{Zn}^{2+}(30 \mu \mathrm{M})\right]$ as demonstrated by the absence of change in the CD spectrum (Figure 2B). It is noteworthy that $\mathrm{LCC}^{\mathrm{Tb}}$ can bind $\mathrm{Cu}^{+}$but not $\mathrm{Cu}^{2+}$.

The coordination of $\mathrm{Cu}^{+}$or $\mathrm{Ag}^{+}$was further investigated by electronic absorption spectroscopy and photolumines cence to gain further insight into the establishment and effect of a cation $\pi$ interaction. Concerning the UV/Vis absorption and the fluorescence of tryptophan, the binding of $\mathrm{Cu}^{+}$or $\mathrm{Ag}^{+}$ is associated with a red shift of the indole $\pi \pi^{*}$ transition absorption band (Figure $3 \mathrm{~A}$ ) and a partial quenching of its
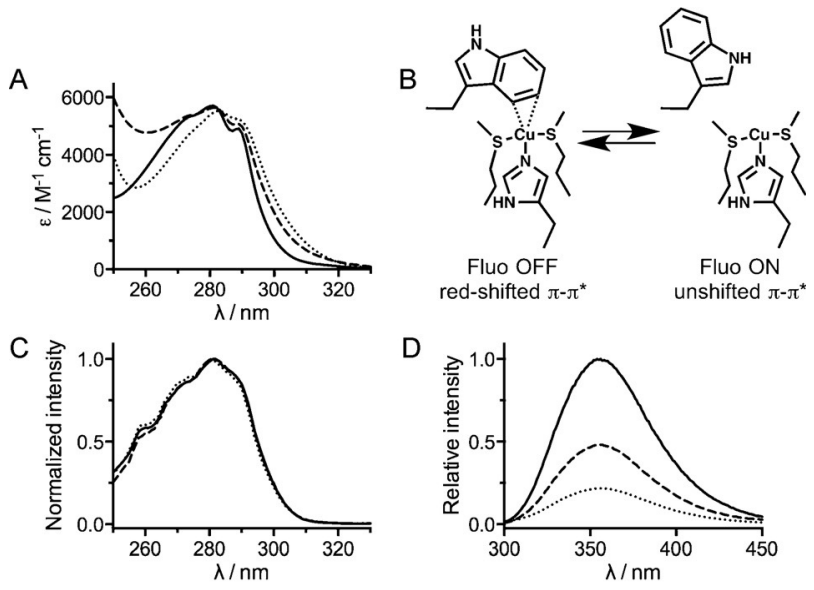

D
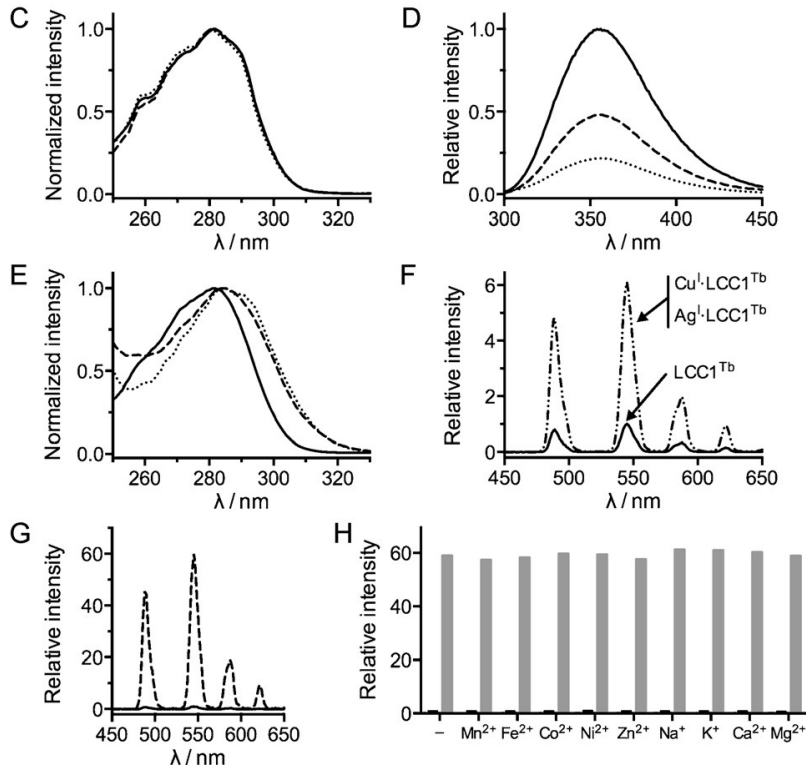

Figure 3. Steady state spectroscopic characterization of $\mathrm{LCCl}^{\mathrm{Tb}}$ (solid line), $\mathrm{Cu}^{\prime} \cdot \mathrm{LCCl}^{\mathrm{Tb}}$ (dashed line), and $\mathrm{Ag}^{\prime} \cdot \mathrm{LCCl}^{\mathrm{Tb}}$ (dotted line). A) Elec tronic absorption spectra. B) Representation of possible fluorescent and non fluorescent forms of tryptophan in $\mathrm{Cu}^{\prime} \cdot \mathrm{LCCl}^{\mathrm{Tb}}$. C,D) Trypto phan fluorescence excitation (C, $\lambda_{\mathrm{em}} 355 \mathrm{~nm}$ ) and emission (D, $\lambda_{\text {ex }} 280 \mathrm{~nm}$ ) spectra. E,F) Time gated $\mathrm{Tb}^{3+}$ luminescence excitation ( $\mathrm{E}, \lambda_{\text {em }} 545 \mathrm{~nm}$ ) and emission ( $\mathrm{F}, \lambda_{\text {ex }} 280 \mathrm{~nm}$ ) spectra. G) Time gated emission spectra with excitation at $310 \mathrm{~nm}$. H) Selectivity diagram showing the time gated $\mathrm{Tb}^{3+}$ emission at $545 \mathrm{~nm}$ $\left(\lambda_{\text {ex }} 310 \mathrm{~nm}\right)$ of $\mathrm{LCCl}^{\mathrm{Tb}}(5 \mu \mathrm{M})$ before (black) and after (grey) addition of 1.5 equiv $\mathrm{Cu}^{+}$in the presence of various cations (from left to right: none, $\mathrm{Mn}^{2+}, \mathrm{Fe}^{2+}, \mathrm{Co}^{2+}, \mathrm{Ni}^{2+}, \mathrm{Zn}^{2+}(10 \mu \mathrm{M}), \mathrm{Na}^{+}, \mathrm{K}^{+}$ $(100 \mathrm{~mm}), \mathrm{Ca}^{2+}$, and $\left.\mathrm{Mg}^{2+}(10 \mathrm{~mm})\right)$. Spectra were recorded in HEPES buffer $(10 \mathrm{~mm}, \mathrm{pH} 7.5)$ under argon.

fluorescence (Figure 3D). This suggests the presence of a cation $\pi$ interaction in $\mathrm{Cu}^{\mathrm{I}} \cdot \mathrm{LCC1}^{\mathrm{Tb}}$ and $\mathrm{Ag}^{\mathrm{I}} \cdot \mathrm{LCC1}^{\mathrm{Tb}}$ as observed for CusF.

The $\mathrm{Tb}^{3+}$ luminescence properties were investigated by exciting the tryptophan antenna at $280 \mathrm{~nm}$, which corre sponds to the maximum absorption of the tryptophan indole $\pi \pi^{*}$ transition in $\mathrm{LCC1}^{\mathrm{Tb}}$. Titrations of $\mathrm{LCC1}^{\mathrm{Tb}}$ by $\mathrm{Cu}^{+}$or $\mathrm{Ag}^{+}$show that the formation of $\mathrm{Cu}^{\mathrm{I}} \cdot \mathrm{LCCl}^{\mathrm{Tb}}$ and $\mathrm{Ag}^{\mathrm{I}} \cdot \mathrm{LCCl}^{\mathrm{Tb}}$ is associated with an increase of the $\mathrm{Tb}^{3+}$ emission. The $\mathrm{Tb}^{3+}$ luminescence excitation spectra of $\mathrm{LCC}^{\mathrm{Tb}}, \mathrm{Cu}^{\mathrm{I}} \cdot \mathrm{LCC1}^{\mathrm{Tb}}$, and $\mathrm{Ag}^{\mathrm{I}} \cdot \mathrm{LCCl}^{\mathrm{Tb}}$ (Figure $3 \mathrm{E}$ ) correspond to the $\pi \pi^{*}$ transition observed in the electronic absorption spectra, indicating that the tryptophan acts as an antenna for $\mathrm{Tb}^{3+}$ in $\mathrm{LCC1}^{\mathrm{Tb}}$ and its $\mathrm{Cu}^{+}$or $\mathrm{Ag}^{+}$complexes. Interestingly, the $\mathrm{Tb}^{3+}$ excitation spectra $\left(\lambda_{\mathrm{em}}=545 \mathrm{~nm}\right)$ of $\mathrm{Cu}^{\mathrm{I}} \cdot \mathrm{LCC1}^{\mathrm{Tb}}$ and $\mathrm{Ag}^{\mathrm{I}} \cdot \mathrm{LCC1}^{\mathrm{Tb}}$ are red shifted compared to $\mathrm{LCC1}^{\mathrm{Tb}}$ (Figure $3 \mathrm{E}$ ), but the trypto phan fluorescence excitation spectra $\left(\lambda_{\mathrm{em}}=355 \mathrm{~nm}\right)$ are not 
(Figure 3C). This is consistent with two kinds of tryptophan indole that are present in solution when $\mathrm{Cu}^{+}$or $\mathrm{Ag}^{+}$are bound to $\mathrm{LCCl}^{\mathrm{Tb}}$ : one corresponding to an indole that is fluorescent and has an unshifted $\pi \pi^{*}$ transition and the other one corresponding to a non fluorescent indole with a red shifted $\pi \pi^{*}$ transition and a higher $\mathrm{Tb}^{3+}$ luminescence. As the cation $\pi$ interaction in CusF totally quenches the tryptophan fluorescence, we can propose that two forms of the 1:1 complex co exist in solution, one with the tryptophan indole establishing a cation $\pi$ interaction and the other not (Figure 3B). Figure 3F compares the time gated $\mathrm{Tb}^{3+}$ emis sion spectra of $\mathrm{LCC1}^{\mathrm{Tb}}, \mathrm{Cu}^{\mathrm{I}} \cdot \mathrm{LCC1}^{\mathrm{Tb}}$, and $\mathrm{Ag}^{\mathrm{I}} \cdot \mathrm{LCC1}^{\mathrm{Tb}}$ with excitation at $280 \mathrm{~nm} . \mathrm{Cu}^{+}$and $\mathrm{Ag}^{+}$enhance the $\mathrm{Tb}^{3+}$ emission six times with respect to $\mathrm{LCC1}^{\mathrm{Tb}}$ and thus, $\mathrm{LCC1}^{\mathrm{Tb}}$ acts as a turn on luminescent probe for these cations. Moreover, the red shift of the indole $\pi \pi^{*}$ transition can be used to increase the contrast of the probe: $\mathrm{Tb}^{3+}$ luminescence enhancement factors of 58 and 52 were obtained for $\mathrm{Cu}^{+}$and $\mathrm{Ag}^{+}$, respectively, by exciting the probe at $310 \mathrm{~nm}$ (see SI for rationalization of this wavelength choice) instead of $280 \mathrm{~nm}$ (Figure $3 \mathrm{G}$ ). Furthermore, the $\mathrm{Tb}^{3+}$ emission of $\mathrm{LCC1}^{\mathrm{Tb}}$ and $\mathrm{Cu}^{\mathrm{I}} \cdot \mathrm{LCC}^{\mathrm{Tb}}$ is not affected by the presence of physiological cations (Figure $3 \mathrm{H}$ ). Overall, $\mathrm{LCC1}^{\mathrm{Tb}}$ is a high contrast turn on luminescent probe for the time gated detection of $\mathrm{Cu}^{+}$ among physiological cations. It is also able to detect $\mathrm{Ag}^{+}$. The binding constants for $\mathrm{Cu}^{+}$and $\mathrm{Ag}^{+}$, determined by competi tion experiments with imidazole are $10^{9.4} \mathrm{M}^{-1}$ and $10^{7.3} \mathrm{M}^{-1}$, respectively (SI). The $K_{\mathrm{M}}$ for other physiological cations is estimated to be below $10^{3} \mathrm{M}^{-1}$.

The enhancement of $\mathrm{Tb}^{3+}$ luminescence upon $\mathrm{Cu}^{+}$or $\mathrm{Ag}^{+}$ binding may originate from 1) a reduction of the number of water molecules bound to $\mathrm{Tb}^{3+}, 2$ ) a change in photophysical processes caused by the cation $\pi$ interaction, or 3 ) a con formational change, that is, a shortening of the distance between the antenna and the $\mathrm{Tb}^{3+}$ ion and/or a change in the orientation of the antenna with respect to $\mathrm{Tb}^{3+}$. Concerning the latter point, changes in $\mathrm{CD}$ upon $\mathrm{Cu}^{+}$or $\mathrm{Ag}^{+}$binding may arise from conformational changes but also from the con tribution of ligand metal charge transfer transitions. The NMR spectra of $\mathrm{LCC1}^{\mathrm{La}}$, the diamagnetic homologous probe in which the $\mathrm{Tb}^{3+}$ ion is replaced by a $\mathrm{La}^{3+}$ ion, and of its $\mathrm{Cu}^{+}$ or $\mathrm{Ag}^{+}$complexes display broad resonances that preclude any structural analysis, unfortunately. To elucidate the mechanism of the $\mathrm{Tb}^{3+}$ luminescence enhancement and quantify fast processes, the emission of the probe was characterized in detail. Regarding $\mathrm{Tb}^{3+}$ emission, $\mathrm{Cu}^{+}$or $\mathrm{Ag}^{+}$binding has almost no effect on the luminescence lifetime $(\tau \approx 1.9 \mathrm{~ms})$. Measurements of luminescence lifetime values in $\mathrm{H}_{2} \mathrm{O}$ and $\mathrm{D}_{2} \mathrm{O}$ additionally showed that only one water molecule is coordinated to the $\mathrm{Tb}^{3+}$ ion in $\mathrm{LCCl}^{\mathrm{Tb}}$ and its $\mathrm{Cu}^{+}$and $\mathrm{Ag}^{+}$ complexes (SI). ${ }^{[7,18,21]}$ Therefore, the enhancement of $\mathrm{Tb}^{3+}$ emission is not due to a change in the $\mathrm{Tb}^{3+}$ primary coordination sphere. Emission was further investigated at the ns and $\mu$ s timescale by time resolved emission spectros copy with streak camera detection. The fluorescence of $\mathrm{LCC}^{\mathrm{Tb}}$ is characterized by a bi exponential decay $\left(\tau_{1}=\right.$ $0.9 \mathrm{~ns}$ and $\tau_{2}=4.8 \mathrm{~ns}$, Table 1 ), which is common for trypto phan. ${ }^{[22]}$ The lifetimes of the fluorescence of $\mathrm{Cu}^{\mathrm{I}} \cdot \mathrm{LCC}^{\mathrm{Tb}}$ and $\mathrm{Ag}^{\mathrm{I}} \cdot \mathrm{LCCl}^{\mathrm{Tb}}$, which accounts for the species with the indole
Table 1: Decay lifetimes of tryptophan emission and rise time of $\mathrm{Tb}^{3+}$ emission for $\mathrm{LCCl}^{\mathrm{Tb}}, \mathrm{Cu}^{\prime} \cdot \mathrm{LCCl}^{\mathrm{Tb}}$, and $\mathrm{Ag}^{\mathrm{l}} \cdot \mathrm{LCCl}^{\mathrm{Tb}}$. Error on $\tau$ values is estimated at $10 \%$.

\begin{tabular}{|c|c|c|c|}
\hline Compound & $\begin{array}{l}\text { Tryptophan fluo } \\
\text { rescence decay } \\
\text { (ns) }\end{array}$ & $\begin{array}{l}\text { Tryptophan phos } \\
\text { phorescence decay } \\
(\mu \mathrm{s})\end{array}$ & $\begin{array}{l}\mathrm{Tb}^{3+} \text { lumines } \\
\text { cence rise }(\mu \mathrm{s})\end{array}$ \\
\hline $\mathrm{LCCl}^{\mathrm{Tb}}$ & $\begin{array}{l}0.9(13 \%) \\
4.8(87 \%)\end{array}$ & not detected & 23 \\
\hline $\mathrm{Cu}^{\prime} \cdot \mathrm{LCCl}^{\mathrm{Tb}}$ & $\begin{array}{l}0.7 \text { (16\%), } \\
3.9(84 \%)\end{array}$ & 16 & 16 \\
\hline $\mathrm{Ag}^{\prime} \cdot \mathrm{LCCl}^{\mathrm{Tb}}$ & $\begin{array}{l}0.9 \text { (17\%), } \\
4.2(83 \%)\end{array}$ & 19 & 18 \\
\hline $\mathrm{Cu}^{\prime} \cdot \mathrm{LCCl}^{\mathrm{La}}$ & & 18 & \\
\hline $\mathrm{Ag}^{\prime} \cdot \mathrm{LCC}^{\mathrm{La}}$ & & 20 & \\
\hline
\end{tabular}
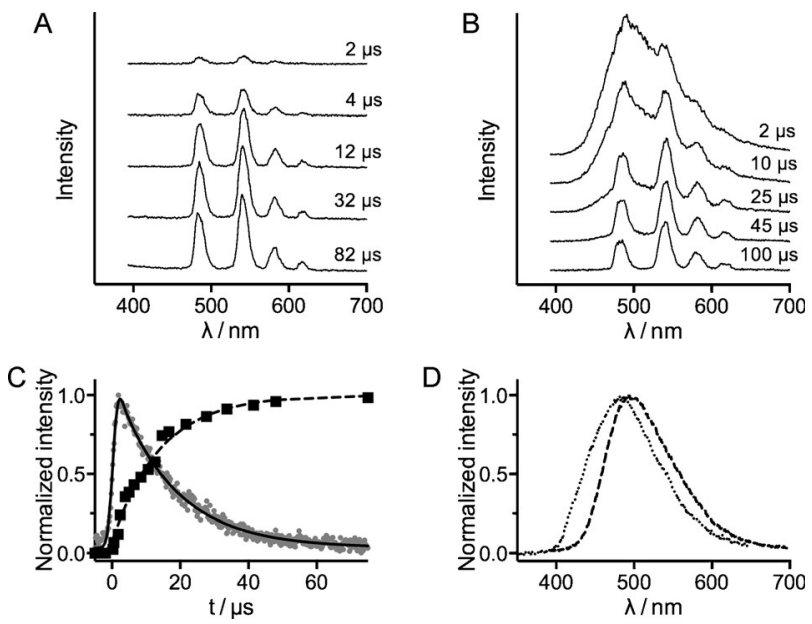

Figure 4. Time resolved emission spectroscopy in degassed buffer solutions. Spectra were recorded in time gated mode using a streak camera $\left(\lambda_{\text {ex }} 266 \mathrm{~nm}\right)$. Time resolved emission spectra of $\left.A\right) \mathrm{LCCl}^{\mathrm{Tb}}$ and $\mathrm{B}$ ) $\mathrm{Cu}^{\prime} \cdot \mathrm{LCCl}^{\mathrm{Tb}}$ recorded several $\mu$ s after the laser pulse $(2 \mu \mathrm{s}$ integration time). C) Evolution of the tryptophan phosphorescence emission at $440 \mathrm{~nm}$ (dots) and of the $\mathrm{Tb}^{3+}$ emission at $545 \mathrm{~nm}$ (square; the tryptophan phosphorescence has been subtracted) for $\mathrm{Cu}^{\mathrm{I}} \cdot \mathrm{LCCl}^{\mathrm{Tb}}$. The solid and dashed lines correspond to the respective fits which yielded $\tau \quad 16 \pm 2 \mu$ s for both phosphorescence decay and $\mathrm{Tb}^{3+}$ emission grow in. D) Phosphorescence emission spectra of $\mathrm{Cu}^{\prime} \cdot \mathrm{LCC}^{\mathrm{La}}$ (dashed line) and $\mathrm{Ag}^{\prime} \cdot \mathrm{LCC}^{\mathrm{La}}$ (dotted line).

not involved in a cation $\pi$ interaction, are similar. Emission on the $\mu$ s timescale was investigated in a time gated mode to eliminate the tryptophan fluorescence signal (SI).

Figures $4 \mathrm{~A}$ and $4 \mathrm{~B}$ compare the emission spectra of $\mathrm{LCC}^{\mathrm{Tb}}$ and $\mathrm{Cu}^{\mathrm{I}} \cdot \mathrm{LCC}^{\mathrm{Tb}}$ recorded several $\mu$ s after the laser pulse $\left(\lambda_{\mathrm{ex}}=266 \mathrm{~nm}, 2 \mu\right.$ s integration time $)$. For $\mathrm{LCC1}^{\mathrm{Tb}}$, the rise of $\mathrm{Tb}^{3+}$ luminescence is the only observed emission with a rise time of $23 \mu \mathrm{s}$. This rise time on the $\mu$ s scale is in agreement with a sensitization of the $\mathrm{Tb}^{3+}$ taking place by energy transfer from the triplet state of the tryptophan. However, tryptophan triplet emission could not be detected for $\mathrm{LCC1}^{\mathrm{Tb}}$ or for $\mathrm{LCC1}^{\mathrm{La}}$, the homologous probe with the non luminescent $\mathrm{La}^{3+}$ ion. Conversely, for $\mathrm{Cu}^{\mathrm{I}} \cdot \mathrm{LCC1}^{\mathrm{Tb}}$, the growing $\mathrm{Tb}^{3+}$ emission overlaps with a broad emission band that decays with a lifetime of $16 \mu$ s, which is synchronous with 
the rise of $\mathrm{Tb}^{3+}$ emission $(\tau=16 \mu$ s, Figure $4 \mathrm{C})$. The broad decaying emission band is clearly seen with the $\mathrm{Cu}^{+}$complex of $\mathrm{LCC}^{\mathrm{La}}$ (Figure 4D). Due to its lifetime in the $\mu$ s scale and spectrum, this band can be attributed to the triplet emission of the tryptophan. This confirms that $\mathrm{Tb}^{3+}$ sensitization occurs through a tryptophan $\left(\mathrm{T}_{1}\right)$ to $\mathrm{Tb}^{3+}\left({ }^{5} \mathrm{D}_{4}\right)$ energy transfer. $\mathrm{Ag}^{\mathrm{I}} \cdot \mathrm{LCC1}^{\mathrm{Ln}}(\mathrm{Ln}=\mathrm{Tb}$ or $\mathrm{La})$ behaves in the same way as $\mathrm{Cu}^{\mathrm{I}} \cdot \mathrm{LCC1}^{\mathrm{Ln}}$ but with blue shifted tryptophan phosphores cence emission compared to the analogous copper complex (Figure 4D). The above results show that both $\mathrm{Cu}^{+}$and $\mathrm{Ag}^{+}$ binding to $\mathrm{LCC} 1^{\mathrm{Tb}}$ increase tryptophan triplet state emission as well as $\mathrm{Tb}^{3+}$ emission. Together with the loss of tryptophan fluorescence for the 1:1 complex conformer that establishes a cation $\pi$ interaction, this is compatible with an ISC enhancement promoted by the cation $\pi$ interaction. ${ }^{[15]}$ There fore, the binding of $\mathrm{Cu}^{+}$or $\mathrm{Ag}^{+}$to $\mathrm{LCC}^{\mathrm{Tb}}$ through a cation $\pi$ interaction favors ISC and increases the population of the excited triplet state of the tryptophan. Hence, more energy can be transferred to the $\mathrm{Tb}^{3+5} \mathrm{D}_{4}$ excited state, which in turn emits more. Although it cannot be excluded that conforma tional changes may be, in part, responsible for $\mathrm{Tb}^{3+}$ lumines cence enhancement, the spectroscopic data presented here point to a major role of the cation $\pi$ interaction that is established between the metal ion and the tryptophan indole. In addition to the global ISC enhancement, the cation $\pi$ interaction with $\mathrm{Cu}^{+}$and $\mathrm{Ag}^{+}$shifts the tryptophan triplet excited state emission but to a different extent. Indeed, comparison of the room temperature phosphorescence spec tra of $\mathrm{Cu}^{\mathrm{I}} \cdot \mathrm{LCC}^{\mathrm{La}}$ and $\mathrm{Ag}^{\mathrm{I}} \cdot \mathrm{LCC} 1^{\mathrm{La}}(\mathrm{SI})$ with those reported in the literature for proteins ${ }^{[23,24]}$ show that $\mathrm{Cu}^{+}$and $\mathrm{Ag}^{+}$lower the energy of the excited triplet state of tryptophan by ca. $2300 \mathrm{~cm}^{-1}$ and $500 \mathrm{~cm}^{-1}$, respectively.

Here we describe a new luminescent probe for selective $\mathrm{Cu}^{+}$detection among physiological cations. This probe is characterized by a high contrast and long lived emission of its $\mathrm{Tb}^{3+}$ ion, which allows time gated detection. Additionally, detailed spectroscopic characterization shows that the cation $\pi$ interaction established between the metal ion and the tryptophan indole plays a major role in modulating the $\mathrm{Tb}^{3+}$ luminescence in this prototype by modulation of the photo physical properties of the tryptophan antenna. As cation $\pi$ interactions may be formed with several cations (e.g., $\mathrm{Cu}^{+}$, $\mathrm{Ag}^{+}, \mathrm{Cd}^{2+}, \mathrm{Hg}^{2+}$, and $\mathrm{Pb}^{2+}$ ), this work paves the way for the design of lanthanide based luminescent probes for $\mathrm{Cu}^{+}$or toxic cations with desirable emission properties relying on a mechanism other than metal induced PET quenching.

\section{Acknowledgements}

O.S. acknowledges the support of the Agence Nationale de la Recherche (ANR 12 BS07 0012 01) and Labex ARCANE (ANR 11 LABX 0003 01).
Keywords: cation $\pi$ interactions - copper - luminescence . peptides $\cdot$ terbium

[1] S. J. Lippard, J. M. Berg, Principles of Bioinorganic Chemistry, University Science Books, Mill Valley, CA, 1994.

[2] B. E. Kim, T. Nevitt, D. J. Thiele, Nat. Chem. Biol. 2008, 4, 176 185.

[3] P. Delangle, E. Mintz, Dalton Trans. 2012, 41, 63596370.

[4] R. McRae, P. Bagchi, S. Sumalekshmy, C. J. Fahrni, Chem. Rev. 2009, 109, 47804827.

[5] C. J. Fahrni, Curr. Opin. Chem. Biol. 2013, 17, 656662.

[6] J. A. J. Cotruvo, A. T. Aron, K. M. Ramos Torres, C. J. Chang, Chem. Soc. Rev. 2015, 44, 44004414.

[7] J. C. G. Bünzli, C. Piguet, Chem. Soc. Rev. 2005, 34, 10481077.

[8] J. C. G. Bünzli, Chem. Rev. 2010, 110, 27292755.

[9] A. Thibon, V. C. Pierre, Anal. Bioanal. Chem. 2009, 394, 107 120.

[10] H. J. Tanke in Lanthanide Luminescence (Eds.: P. Hänninen, H. Härmä), Springer, Berlin, 2011, pp. 313328.

[11] E. H. Kim, C. Rensing, M. M. McEvoy, Nat. Prod. Rep. 2010, 27, 711719.

[12] J. A. Delmar, C. C. Su, E. W. Yu, Biometals 2013, 26, 593607.

[13] I. R. Loftin, S. Franke, N. J. Blackburn, M. M. McEvoy, Protein Sci. 2007, 16, 22872293.

[14] Y. Xue, A. V. Davis, G. Balakrishnan, J. P. Stasser, B. M. Staehlin, P. Focia, T. G. Spiro, J. E. Penner Hahn, T. V. O'Hal loran, Nat. Chem. Biol. 2008, 4, $107 \quad 109$.

[15] H. Masuhara, H. Shioyama, T. Saito, K. Hamada, S. Yasoshima, N. Mataga, J. Phys. Chem. 1984, 88, 58685873.

[16] S. V. Eliseeva, J. C. G. Bünzli, Chem. Soc. Rev. 2010, 39, 189 227.

[17] M. C. Heffern, L. M. Matosziuk, T. J. Meade, Chem. Rev. 2014, 114, 44964539.

[18] J. C. G. Bünzli, S. V. Eliseeva in Lanthanide Luminescence (Eds.: P. Hänninen, H. Härmä), Springer, Berlin, 2011, pp. 145.

[19] W. Horrocks, B. Holmquist, B. Vallee, Proc. Natl. Acad. Sci. USA 1975, 72, 47644768

[20] U. S. Raghavender, S. Aravinda, R. Rai, N. Shamala, P. Balaram, Org. Biomol. Chem. 2010, 8, 31333135.

[21] A. Beeby, I. M. Clarkson, R. S. Dickins, S. Faulkner, D. Parker, L. Royle, A. S. de Sousa, J. A. G. Williams, M. Woods, J. Chem. Soc. Perkin Trans. 2 1999, 493504.

[22] J. R. Lakowicz, Principles of Fluorescence Spectroscopy, Springer, New York, 2006.

[23] Y. Kai, K. Imakubo, Photochem. Photobiol. 1979, 29, 261265.

[24] V. M. Mazhul', A. V. Timoshenko, E. M. Zaitseva, S. G. Lozni kova, I. V. Halets, T. S. Chernovets, Reviews in Fluorescence, Springer, Dordrecht, 2008, pp. 3767. 